\title{
Regulated Hatred in Sense and Sensibility (1811) and Persuasion (1816) by Jane Austen
}

\author{
Najlaa Hosny Ameen Mohammed \\ Assistant Professor of English Literature, English Department, Vice-Dean of Huraymilaa College of Science and Humanities, Shaqra \\ University, Riyadh, Kingdom of Saudi Arabia
}

\section{Email address:}

nhsayn@su.edu.sa

To cite this article:

Najlaa Hosny Ameen Mohammed. Regulated Hatred in Sense and Sensibility (1811) and Persuasion (1816) by Jane Austen. International Journal of Literature and Arts. Vol. 2, No. 4, 2014, pp. 110-122. doi: 10.11648/j.ijla.20140204.15

\begin{abstract}
This research examines the theory of 'regulated hatred' in two masterpieces by Jane Austen: Sense and Sensibility (1811) and Persuasion (1816). To analyse these novels, the paper adopts an interdisciplinary approach, including psychological, biographical, and New Historicist approaches; taking its inspiration from the theory initially introduced by D. W. Harding in his article 'Regulated Hatred: An Aspect of the work of Jane Austen' (1940), alongside C. J. Jung's theory of 'the formation of artist's creativity' highlighted in his article 'Psychology and Literature' (1930). The study is divided into three sections. The first section introduces the theoretical aspects of the research, outlining Harding and Jung's theories. A brief overview of the plot of the two novels is set out, to assist in establishing the author's narrative techniques. The second section investigates the psychological theories of Austen's two novels Persuasion and Sense and Sensibility in reference to the theoretical framework. There is also an examination of the ways in which Austen employs her hatred toward both her enemies and unpolished manners in society, through an examination of her narrative techniques from a psychological, biographical and New Historicist approach. These include: her varying tones, her artistic representation, her tyrannical style and intellectual perspective, and the unequal treatment of her characters. In addition, there is a discussion of Austen's motives in writing these two novels. This section discusses the assumptions behind the attempt to deduce new literary, social and political interpretations of Austen's art, examining her novels as, amusement and entertainment, social critique, or as an outlet of her inner emotion with the aim of reforming the ills of society. The third section illustrates the ways in which Austen adopts a new form of realism; in particular, how she employs her pen to revolutionise the ruling standards of social groups. Austen is seen to address the internal struggles of society successfully, by sympathising with, or disdaining, her characters in both novels. The study, therefore, offers a complementary understanding of the inner psychology of the creative Jane Austen, as well as of her art and the era in which she lived.
\end{abstract}

Keywords: Introduction, Theoretical Framework, Jane Austen's Characters, Conclusion

\section{Introduction}

The novel is a flexible and free literary genre. Among its salient features are that its language renews itself by incorporating numerous layers of literary language, permeated with laughter, irony, humour, satire, and an infinite number of artistic techniques to disclose reality. This research begins by introducing the ways in which the well-known author, Jane Austen, employed her novels Persuasion and Sense and Sensibility to express the moral and social reality of the nineteenth century, with an emphasis on the techniques she adopted to reveal her viewpoint. The hypothesis behind this research is that regulated hatred is an important aspect in both novels, which are deemed not only as a source of relief, entertainment and amusement, but also as a severe (although disguised) social criticism of nineteenth-century manners. Like Shakespeare before her, Austen utilised her pen to send masked and indirect messages to those individuals around her that she found distasteful.

\section{Theoretical Framework}

This section will illuminate the theories of Harding and Jung. 


\subsection{W. Harding and Psychological Theory}

Denys Clement Wyatt Harding (1906-1993) is a professor of psychology and eminent critic of English Literature. Harding asserts that good literary criticism provides a similar level of enjoyment to novels, but with a far smaller commitment of time and energy. He has written a number of different essays focusing on "Austen's concern with the survival of the sensitive and penetrating individual in a society of conforming mediocrity". Moreover, Harding's critical method is viewed as an amalgam of:

an acute sensitivity to Austen's fictional techniques with an informed understanding of the social and historical particulars that conditioned the possibilities for the precise responses of characters in the worlds that surround them. (Justice, 1998)

Harding first published his well-known article "Regulated Hated: An Aspect in the Work of Jane Austen" in 'Scrutiny', during the 1940s. He began with the skewed emphasis that it is distasteful to read Jane Austen as the writings of 'cosy' and hypocritical hagiographers ${ }^{1}$ : a conventional notion he fiercely attacks. He offers two assumptions: the first indicates that many critics and readers admire her texts as a source of amusement; the second is that her texts imply regulated hatred and embedded criticism towards the ill manners and distasteful individuals within her society. This research attempts to scrutinise Austen's two novels from the perspectives raised by these two assumptions, employing a psychological envisioning, hence the additional introduction of Jung's theory of the artist's creativity.

\subsubsection{First Assumption}

Austen's novels have been viewed as a source of relief and excitement, both by the public and first-hand critics, as echoed in histories of literature, university courses, literary journalism, and polite allusions. To illustrate, due to the atmosphere surrounding her work, she offered an exceptionally favourable exposition of urbanity. Many are excited by the impression that "she provided a refuge for the sensitive when the contemporary world grew too much for them"; Harding mentions Beatrice Kean Seymour's quotation in regard to Austen's novels:

In a society which has enthroned the machine-gun and carried it aloft even into the quiet heavens, there will always be men and women-Escapist or not, as you pleasewho will turn to her novels with an unending sense relief and thankfulness. (Harding, 1940: 260)

She is viewed as having succeeded admirably in expressing the gentler virtues of a civilised social order. Harding also asserts that:

she was a delicate satirist, revealing with inimitable lightness of touch the comic foibles and amiable

\footnotetext{
${ }^{1} \mathrm{~A}$ hagiography is designed to serve a political agenda. Oxford Dictionary of English, $7^{\text {th }}$ ed., 2010.
}

weaknesses of the people whom she lived among and liked (Harding, 1940: 263).

\subsubsection{Second Assumption}

However, after an in depth examination of her novels, Harding concludes that there is "a seriously misleading impression". He notices:

Fragments of truth have been incorporated in it but they are fitted into a pattern whose total effect is false. And yet the wide currency of this false impression is an indication of Jane Austen's impression is an indication of Jane Austen's success in an essential part of her complex intention as a writer: her books are, as she meant them to be, read and enjoyed by precisely the sort of people whom she disliked; she is a literary classic of the society attitudes like hers, held widely enough, would undermine. ((Harding, 1940: 264)

Harding draws the readers' attention to the fact that "unexpected astringencies occur which the comfortable reader probably overlooks, or else passes by as slight imperfections, trifling errors of tone brought about by a faulty choice of words" (Harding, 1940: 265). Since Harding focuses primarily on Mansfield Park, Northanger Abbey, Emma and Pride and Prejudice, the analysis presented in this research will complement this work by focusing on Persuasion and Sense and Sensibility.

\subsection{G. Jung and Psychological Theory}

Carl Gustav Jung (1875-1961) was a student of Freud, but his perspective was more congenial to literature. In his preface, David Lodge illustrates that Jung was:

much more sympathetic than Freud towards visionary, religious and even magical traditions, readily endorsed the claims of literature to embody knowledge-knowledge of a kind particularly vital to alienated, secularised modern man; and his assertion that it is his art that explains the artist, not the insufficiencies and conflicts of his personal life He established his own school of analytical psychology. (1972: 174)

In his article 'Psychology and Literature' (1930), Jung also asserts that psychology is the study of psychic processes or activities. The study of literature for the human psyche is viewed as the womb of all the sciences and arts. Thus, psychological research can be designed to explain both the formation of a work of art and to reveal the factors that make an individual artistically creative. In the first instance, the researcher must attempt a psychological analysis of a definitely circumscribed and concrete artistic achievement, while in the second analysis the living and creative human being is presented as a unique personality (Jung, 1930: 175).

Jung demonstrates that the creative aspect of life (which finds its clearest experience in art) baffles all attempts at rational formulation. Any reaction to stimulus can only be depicted in its manifestations: it can be obscurely and vaguely sensed, but never wholly grasped and attained. It is for this reason that many critics have debated Austen's art, 
and her goals and incentives are still under discussion. It is an important principle of psychology that psychic events are derivable and various. That is to say, it is a principle in the study of art that a psychic product is something in, and for, itself- whether it is the work of art or the artist that is in question. Hence, the researcher attempts to study Austen's inner artistic psychology and the motivations behind her writing.

In order to analyse Austen's two novels satirically and technically, a brief overview of the plot must be introduced first. The first novel Persuasion concerns the Elliots of Kellynch Hall, a family with three daughters (Elizabeth, Anne, Mary) and their father, Sir Walter Elliot. When the family find themselves in financial trouble, they are forced to move to Bath and rent out the family estate to Admiral and Mrs. Croft. Eight and a half years previously, Anne had been persuaded by Lady Russell, a trusted family advisor, to turn down an offer of marriage from Captain Fredrick Wentworth. Wentworth has since (due to the Napoleonic wars) become a man of rank and wealth, and has now come to propose to Louisa, the sister of Anne's brother-in-law. Meanwhile Anne's cousin, William Elliot (the heir to Kellynch Hall) seeks out Anne as his wife. During the course of the novel a number of accidents take place that prove the mutual and deep affection between Anne and Wentworth. Louisa eventually becomes engaged to Captain Benwick, a depressed naval officer, mourning the death of his wife. Mrs. Smith, an old friend of Anne (and whom Anne frequently visits as she is poor and sick) reveals the greedy and immoral character of Mr. Elliot, which as caused her husband's bankruptcy. Finally, Anne and Wentworth are reconciled and happily married.

Sense and Sensibility revolves around a widow, Mrs. Dashwood, and her three daughters: Elinor, Marianne and Margaret. Although Mr. Dashwood, on his deathbed, asked his son to promise to take care of his half-sisters, John gives them nothing, because of his greedy wife, Fanny. Due to Fanny's ill-treatment, the mother and her three daughters subsequently relocate to live near the Middletons at Barton Park, where they make new acquaintances. These include a retired officer, Colonel Brandon, and the impetuous John Willoughby. Willoughby openly courts Marianne and she falls deeply in love with him. Rumours of their engagement spread, yet, without warning, Willoughby travels to London leaving, Marianne heartbroken. Meanwhile, Lucy Steele, a new acquaintance of Elinor at Barton, reveals to Elinor her secret engagement to Edward Ferrars, Elinor's beloved. Elinor and Marianne travel to London with their new acquaintance, Lady Middleton's mother, Mrs. Jennings. Colonel Brandon informs Elinor of Willoughby's history of callousness and debauchery. On hearing of Edward's engagement to Lucy Steele, Mrs. Ferrars instantly disinherits him, passing his fortune to his brother, Robert. This change of fortune ensures that Lucy Steele becomes engaged to Robert instead of Edward. Edward proposes to his beloved Elinor, and Marianne and Colonel Brandon also become engaged.
The research will prove its hypotheses by focusing on several characters, examining Austen's literary and intellectual techniques and investigating the incentives behind her writing, in relation to Harding and Jung's psychological theories. The approach is thus psychological, biographical and New Historicist. The New Historicist approach focuses on the manner in which literature can disguise power relations at work within the social context in which it was produced. This often involves forging connections between a literary work and conflicting powers, mainly political (Peck and Coyle, 2002: 182-4).

To establish whether regulated hatred is a prominent aspect in Jane Austen's two novels Persuasion and Sense and Sensibility, this research will investigate the manner in which Austen employs her hatred towards unpolished manners in her society, and towards her enemies, by examining her narrative techniques, her varying tones, art of representation, intellectual perspectives and her treatment of her characters using all three approaches. The aim is to achieve a new literary, social and political interpretation of Austen's art.

\section{Jane Austen's Characters}

This section explores Austen's motivation behind the creation of various characters in the two novels. Some are merely caricatures (through which she humorously criticises the malicious in her society), others are samples of good-nature and perceptive individuals, on which she intends her readers to model themselves, while others serve as 'rakes',(through which she reactivates and shapes her plot).

\subsection{Regulated Hatred Directed Toward Specific Characters}

Harding sheds considerable light on the novelist Jane Austen's sensitive intelligence, living in her world of news and gossip interchanged amongst a large family. Despite the fact that she appreciates the influence of civilisation on society, she vehemently attacks social intercourse riddled with gossip, vulgarity and superficial friendliness. Caricature serves her purpose, allowing her to attack these distasteful figures in a civilised and indirect manner, in the sense that it is difficult to say "where caricature leaves off and the claim to serious portraiture begins" (Harding, 1940:264).

Jane Austen appears to feel profound regulated hatred toward the uncivilised, impertinent and unrefined amongst the upper-middle class characters in her novels. For instance, in Persuasion, Mrs. Clay, is the epitome of 'female vulgarity', 'ill-breeding' and 'triviality'. Mudrick, in his book entitled 'Jane Austen: Irony as Defence and Discovery' illustrates that she is "a lower-class opportunist, determined to rise by humbleness", and, after her unfruitful marriage, she approaches Sir Walter by the "tenacious softness of her personality" and flattery: "flattery is Sir Walter's daily food, and no one feeds him more eagerly 
than Mrs. Clay" (Mudrick, 1952: 210). As Austen states in Chapter Three: “...for Mrs. Clay was present: her father had driven her over, nothing being of so much use to Mrs. Clay's health as a drive to Kellynch" (Persuasion, 2007: 16). Not only does Austen call on her readers to condemn and despise Mrs. Clay's spiteful traits, but she also, according to Mudrick, intervenes to "dissolve into the impassioned participant"(Mudrick, 1952: 211). In Chapter Two, Austen describes Mrs Clay as one "who ought to have been nothing ... but the object of distant civility" (Persuasion, 2007: 14).

Austen has a dual aim in introducing Mrs. Musgrove. Firstly, Austen's 'regulated hatred' is clear in "detecting false currency, or so relentless in exposing it" and in her "impatience against the slack thought and ready-made pretences that pass current in the world" (O'Neill, 1970: 21). This is made clear by Mrs. Musgrove's "large fat sighings over a son whom alive no one had cared for" (Persuasion, 2007: 60).Even his sisters called him 'poor Richard' (Persuasion, 2007: 44). Secondly, Mrs. Musgrove's son is seen as a 'savage caricature' on account of the fact that he "serves as a pretext for abusing Mrs. Musgrove, who 'loves to grieve publicly for the son she lost at sea" (Mudrick, 1952: 211). He is "a thick-headed, unfeeling, unprofitable Dick Musgrove who had never done anything to entitle himself more than the abbreviation of his name, living or dead" (Persuasion, 2007: 44). According to this psychological approach, Austen criticises Mrs. Musgrove for her hypocrisy and insincere grief over her deceased son.

Sir Walter is introduced purposefully by Austen to denote a typical 'rake', that is, to develop events and bring about comic effect, on the one hand, and as a representation of Regency England, through which she sheds light upon Charles II, on the other (Sales, 1996: 172). Mrs. Clay, Mrs. Musgrove and Sir Walter are ultimately defined as 'rakes' that Austen:

could picture them ironically as flirts and agreeable triflers; she could respond to what she considered evil in them, however, not by picturing them, but only by giving them up to the annihilating disapproval of her society (Mudrick, 1952: 221).

Austen's regulated hatred towards Sir Walter Elliot is due to the fact that "vanity was the beginning and the end of Sir Walter Elliot's character; vanity of person and of situation" (Persuasion, 2007: 4). Austen calls him a 'fool' (Persuasion, 2007: 55) and 'not very wise' (Persuasion, 2007: 21) for being totally preoccupied by the physical beauty of "the number of [the] plain women" in Bath (Persuasion, 2007: 123).

From the viewpoint of the New Historicist, Sir Walter's admiration of "his face and figure in a large looking-glasses" and his obsession with a book on baronetage since "he sees his family history as being unique and fascinating", stands for the story of Charles II whose family was "eventually being rewarded for loyal rather than outstanding political services". Sales contends that "it is possible that the title was purchased because it was granted at the accession of Charles II when 'honours, [the Court of Wards and Liveries and Tenures in Capite] were openly on sale"" (1996: 172).

In Persuasion, Mrs. Smith and her sister Nurse Rooke also embody 'rakish' characteristics. However, “Austen's texts can sometimes speak in the voice that they also mock" (Pinion, 1973: 222). Sales puts forward the theory that, despite her marginalisation, Mrs. Smith "still embodies the moral sickness of the high society world she used to inhabit". A cynical gossiper, Mrs. Smith's narrative style is characterised by being circular, rather than linear, in the sense that some information reaches her by an indirect route (Sales, 1996: 196-7): "it does not come to me in quite so direct a line as that; it takes a bend or two, but nothing of consequence" (Persuasion, 2007:178). Moreover, she might stand for the 'regency reader-in-the-text' on the account that she "reads as well as listens to stories about 'silver-fork' life in Bath" (Persuasion, 2007: 197). Mudrick adds that she is "the most tiresome of Jane Austen's characters" (1952: 222) for she is a poverty-stricken and sick widow who takes care of her baby while contriving to make her living through gossip and hand-made products. In other words, Mrs. Smith is considered to represent women's marginalisation in society.

Austen uses Nurse Brooke as a caricature to disclose her 'regulated hatred' for gossip and gossipers in England during the eighteenth century. Harding proposes that "the implications of her caricatures as a criticism of real society, is brought out in the way they dovetail into her social setting" (Harding, 1940: 265). To illustrate, Nurse Brooke's "conversation as well as her medical skills helps to maintain the invalid's morale" (Sales, 1996: 193):

Call it gossip, if you will, but when Nurse Rooke has half an hour's leisure to bestow on me, she is sure to have something to relate that is entertaining and profitable: something that makes one know one's species better. One likes to hear what is going on, to be au fait as to the newest modes of being trifling and silly. To me, who lives so much alone, her conversation, I assure you, is a treat. (Persuasion, 2007: 135)

Austen ironically portrays Nurse Rooke as 'a medical practitioner' who treats the person, as well as the illness. For example, she not only brightens up Mrs. Smith's existence with her gossip, but she encourages her to knit as well; this allows her to make things she can sell to her richer clients. The representation of Nurse Rooke also sheds light upon the Apothecaries' Act of 1815, which did not improve the "lowest rungs of the female midwives' profession". Austen sympathises with the marginalised and demands "some form of regulation and basic training for both male and female midwives" (Sales, 1996: 195). Austen does not customarily explore her historical context in her novels; more typically, she subversively exposes the sickness within society itself, seeking reform and change.

Harding asserts that "Jane Austen pays tribute to the virtuous and fundamentals of her upbringing, ranging herself with those whom she considers right on the simpler 
and more obvious moral issues" (Harding, 1949: 570). To exemplify, Mrs. Palmer, in Sense and Sensibility "enjoys a thorough womanly good-nature". However, "Austen's method of positively representing a mere negative is ingenious and happy" (qtd. in O'Neill, 1970: 15). She is a foolishly good-natured woman who believes that in order to be perfect she ought to imitate the virtuous and refrain from associating with the ill-bred. Richard Simpson points out that "Mrs. Palmer's nullity is represented first by her total want of intellectual discrimination", besides which, "when she talks, her entire want of discrimination is shown in her failure to see the contradiction of contradictories" (O’Neill, 1970: 15). Her speech concerning Willoughby is a good example of the way in which Mrs. Palmer is intended as a thoroughly insane and vain character:

She was determined to drop his acquaintance immediately, and she was very thankful that she had never been acquainted with him at all. She wished with all her heart Combe Magna was not so near Cleveland; but it did not signify, for it was a great deal too far off to visit; she hated him so much that she was resolved never to mention his name again, and she should tell everybody she saw, how good-for-nothing he was. (Sense, 1896: 115)

Harding elaborates that Austen's foible is to "all[y] herself with virtues that are easy to appreciate and reasonably often met with. The result, as one would expect, is "distinct tendency to priggishness" (Harding, 1940: 267).

Hypocrisy, snobbery, false currency and social pretensions are principal among those adverse traits of eighteenth-century society against which Austen launches her attack. For example, in Sense and Sensibility, Fanny (Mrs. John Dashwood) is a typical caricature of the hypocrite, who, after the death of Mr. Dashwood, shows her dislike towards his widow and daughters, treating them as visitors in their own home: "Mrs. John Dashwood now installed herself mistress of Norland; and her mother and sisters-in-law were degraded to the condition of visitors" (Sense and Sensibility, 1896: 5). Her husband, Mr. John Dashwood twists his "father's last request....that [he] should assist his widow and daughters" (Sense, 1896: 5) and (under the pressure of his dominant and greedy wife), is convinced that "five hundred pounds would be a prodigious increase to their fortunes!" (Sense and Sensibility, 1896: 5).

Furthermore, Lucy Steele flatters Lady Middleton and her children excessively to maintain her company, as Lady Middleton is an upper class woman:

I am only waiting to know whether you can make your party without me, or I should have been at my filigree already. I would not disappoint the little angel for all the world: and if you want me at the card-table now, I am resolved to finish the basket after supper.(Sense, 1896: 78)

Lucy Steele is a caricature of the opportunistic, ill-bred female who seeks new acquaintances from among the aristocracy. This is the reason why Lady Middleton prefers the company of Lucy Steele rather than that of Elinor and
Marianne, because of the former's constant flattery of her and her children:

Though nothing could be more polite than Lady Middleton's behaviour to Elinor and Marianne, she did not really like them at all. Because they neither flattered herself nor her children, she could not believe them goodnatured; and because they were fond of reading, she fancied them satirical: perhaps without exactly knowing what it was to be satirical; but THAT did not signify. (Sense, 1896: 131)

Lady Middleton's character in Sense and Sensibility resembles that of Sir Walter in Persuasion; both find excitement and amusement in flattery and social hypocrisy.

It is evident that Austen disapproves of any reserve in "honesty and candour; not only the truth but the whole truth, must be vital of any character of whom she herself is to approve" (O’Neill, 1970: 21). According to Jung's focus on the psychological formation of the artist, Austen is originally formed for "elegant and rational society, excelling in conversation as much as in composition", as described by her brother (qtd. in O’Neill, 1970: 4). Her personality is reflected in the way she treats her characters, as either reasonable or with foibles.

\subsection{Jane Austen's Techniques}

\subsubsection{Jane Austen's Tone}

Jane Austen's tone, whether ironic or disapproving, serves as a good indicator of her regulated hatred towards malicious figures and detestable traits in her class. Harding draws the readers' attention to the fact that "unexpected astringencies occur which the comfortable reader probably overlooks, or else passes by as slight imperfections, trifling errors of tone brought about by a faulty choice of words" (Harding, 1940: 264). Murdick states that:

her tone is personal, only as personality is contained and sheltered in the social mind; and [yet] she escapes an unequivocal involvement by persuading society to applaud and reaffirm its prejudices. (Mudrick, 1952: 207).

For example, in Persuasion, Mudrick states that her tone is full of "a compulsive exasperation turned at unpredictable moments against any character who fails to advance the interests of her heroine"(Mudrick, 1952: 207). Suffering from "the same diffused careless snobbery of smartness and rank" of her 'foolish father', the elder sister, Elizabeth, is contemptuous of Anne, feeling that she herself has had the position of the Lady of Kellynch Hall:

she had the consciousness of being nine-and-twenty to give her some regrets and some apprehensions; she was fully satisfied of being still quite as handsome as ever, but she felt her approach to the years of danger, and would have rejoiced to be certain of being properly solicited by baronet-blood within the next twelvemonth or two. (Persuasion, 2007: 6-7)

In order to save money due to their father's financial distress, Elizabeth takes no gift home for Anne after their yearly visit to London. Furthermore, she does not welcome Anne in Bath: "Then I am sure Anne had better stay, for 
nobody will want her in Bath" (Persuasion, 2007: 29). On behalf of Anne, Austen criticises and avenges for Anne by her victorious tone in saying:

Very, very happy were both Elizabeth and Anne Elliot as they walked in. Elizabeth arm in arm with Miss Carteret, and looking on the broad back of the dowager Viscountess Dalrymple before her, had nothing to wish for which did not seem within her reach; and Anne-but it would be an insult to the nature of Anne's felicity, to draw any comparison between it and her sister's; the origin of one all selfish vanity, of the other all generous attachment. (Persuasion, 2007: 162)

With the same angry, but silent and sheltered tone, Austen expresses her irritation at Sir Walter as "he was not only growing dreadfully in debt" (Persuasion, 2007: 9) because of his extravagant life, but it also led to him being force to rent out his ancestral seat to the Crofts. A New Historicist interpretation suggests that he resembles the Prince of Wales, who sought control of his father's political house, during the Regency Crisis (Sales, 1996: 172).

Austen's disapproving tone is clear in her reserved and indirect dealings with Mrs. Musgrove. To illustrate, Mrs. Musgrove is disdained by Austen since she is unaware of the good values of her sensible protagonist Anne, and is blinded by her snobbish attitude of mourning her son in public, instead:

They were actually on the same sofa, for Mrs Musgrove had most readily made room for him; they were divided only by Mrs Musgrove. It was no insignificant barrier, indeed. Mrs Musgrove was of a comfortable, substantial size, infinitely more fitted by nature to express good cheer and good humour, than tenderness and sentiment; and while the agitations of Anne's slender form, and pensive face, may be considered as very completely screened, Captain Wentworth should be allowed some credit for the self-command with which he attended to her large fat sighings over the destiny of a son, whom alive nobody had cared for. (Persuasion, 2007: 60)

In addition to Mrs. Musgrove, her helpless son pains Austen for "he had been sent to sea, because he was stupid and unmanageable on shore" (Persuasion, 2007: 44). The author's personal attitude of being intolerant and vengeful against malicious and snobbish characters is reflected through Austen's varying tones. Her tone is the mirror of her temperament.

\subsubsection{Austen's Art of Representation}

Austen skilfully displays powerful sentiments, vivid imagination, sound sensibilities and deep insights into her characters: her style is marked with 'the economy of art' (qtd. in O'Neill, 1970: 8). Austen is skilled in representing lively characters and lifelike actions, in controlling the language her characters speak, and in drawing diverse social situations through which she can convey her perceptive messages. For example, in Sense and Sensibility, Mrs. Jennings is a portrait of the aristocratic woman who has no occupation or hobbies and finds interest in making new social acquaintances:

Mrs. Jennings was a widow with an ample jointure. She had only two daughters, both of whom she had lived to see respectably married, and she had now therefore nothing to do but to marry all the rest of the world. In the promotion of this object she was zealously active, as far as her ability reached; and missed no opportunity of projecting weddings among all the young people of her acquaintance. She was remarkably quick in the discovery of attachments, and had enjoyed the advantage of raising the blushes and the vanity of many a young lady by insinuations of her power over such a young man (Sense, 1896: 20).

Austen is not only "a delicate satirist, revealing with inimitable lightness of touch the comic foibles and amiable weaknesses of the people whom she lived among and liked", but also she offers an "exceptionally favourable opening to the exponents of urbanity" (Harding, 1940: 263).

The same exuberant style can be found in Persuasion in the description of Captain Frederick Wentworth:

He had always been lucky; he knew he should be so still. Such confidence, powerful in its own warmth, and bewitching in the wit which often expressed it, must have been enough for Anne... His sanguine temper, and fearlessness of mind, operated very differently on her. She saw in it but an aggravation of the evil. It only added a dangerous character to himself. He was brilliant, he was headstrong. (Persuasion, 2007: 24)

Mudrick states that Captain Wentworth "possesses all the new bourgeois virtues- confidence, aggressiveness, daring eye money and the main chance" (qtd. in O'Neill, 1970: 69). Being a man of feeling and a man of business, Captain Wentworth is regarded by Pinion as "the centre of the stage" (1973: 129), and is viewed as attractive both by Austen and her protagonist Anne.

In her books, Austen rewards her sensible 'differentfrom-the-rest' heroine by ensuring that she is finally married to the handsome, sensible and sensitive bachelor prince. Persuasion mocks the convention of love at first sight. Austen develops her plot expressing "conservative scepticism about the truth of man's spontaneous feeling" (qtd. in Walder, 1896: 229). It is only at the end of the novel that Anne and Wentworth marry, after their feelings have developed, their understandings deepened and their love has grown. Besides which, marriage at the end of a conservative novel is the fulfilment of a personal moral quest.

In Sense and Sensibility, Murdick illustrates that Marianne is "the life and centre of the book" (qtd. in O'Neill, 1970: 100), Austen describes her in Chapter One:

She had an excellent heart;--her disposition was affectionate, and her feelings were strong; but she knew how to govern them: it was a knowledge which her mother had yet to learn; and which one of her sisters had resolved never to be taught. (Sense, 1896:3)

The heroine's sensitivity and finer moral insights are seen as being sanctioned by good-breeding and religious 
civilisation: "it hasn't the power that comes from having created or moulded her, and it can claim no credit for her being what she is" (Harding, 1940: 269). The quality of her representation stands out as characteristic and remarkable in the drawing of her characters.

\subsubsection{Austen's Tyrannical Style}

In contrast, a large number of critics attack Austen's 'dramatic ventriloquism', in the sense that she makes her characters her 'mouth-pieces' (qtd. in O’Neill, 1970: 8). Her tyrannical style is mirrored in her tone. In his article 'A Great Victorian Assessment of Jane Austen', Lewes states that "she loses her hold on us directly she ceases to speak through the personae; she is then like a great actor off the stage" (qtd. in O'Neill, 1970: 10). Kavanagh also concurs with Lewes on this point, adding that the only defect in Miss Austen's works is "that everything is said in the same tone" and that "she could not speak the language of any strong feeling, even though that feeling were ridiculous and unjust" (O'Neill, 1970: 12). To illustrate, her monotonous tone may reflect the fact that:

the people she hated were tolerated, accepted, comfortably ensconced in the only human society she knew; they were, for her society's embarrassing unconscious comment on itself. (Harding, 1940: 263)

Her tyrannical style is also evident in extracts of dialogue. Morgan speaks of the tyranny of convention over "the means employed to pass from dialogue to narrative and back again' (qtd. in Lascelles, 102).An example of this is the following conversation in Chapter Six of Persuasion:

Anne gave her credit, indeed, for feelings of great consideration towards herself, in all that related to Kellynch, and it pleased her: especially, as she had satisfied herself consequently full of strength and courage, till for a moment electrified by Mrs Croft's suddenly saying,-

"It was you, and not your sister, I find, that my brother had the pleasure of being acquainted with, when he was in this country."

Anne hoped she had outlived the age of blushing; but the age of emotion she certainly had not.

"Perhaps you may not have heard that he is married?" added Mrs Croft.

She could now answer as she ought; and was happy to feel, when Mrs Croft's next words explained it to be Mr Wentworth of whom she spoke. (2007: 43)

The same style, showing Austen intervening in the dialogue repeatedly, is apparent in Sense and Sensibility:

Marianne felt for her most sincerely; but she did more harm than good to the cause, by turning very red and saying in an angry manner to Margaret,

"Remember that whatever your conjectures may be, you have no right to repeat them."

"I never had any conjectures about it," replied Margaret; "it was you who told me of it yourself."

This increased the mirth of the company, and Margaret was eagerly pressed to say something more. (2007: 31)
Despite various habits and colours of expression, Austen's style is marked with a jarring sensation of transition and consciousness. Lascelles substantiates the fact that her grand style differs from the eighteenth-century novelists, in the sense that her ambitious consciousness results in an unaffected style for a plain relation of situations and circumstances (Lascelles, 1993: 103). Her narrative is introduced through the depiction of her characters involved in interrelated social interactions, and the description of their situation.

Austen's art lacks impersonality, which is held to be among the characteristics of the artistic novelist. Not only Flaubert, but also the intellectual Anton Chekov, highlighted the fact that the novelist should be as objective as possible, and not impose either their own standpoint or tone on the text, characters or reader. Lubbock remarks that:

a really artistic writer ought not to appear in his story at all. But of course with every touch that he lays on his subject he must show what he thinks of it; his subject, indeed, the book which he finds in his selected fragment of life, is purely the representation of his view, his judgment, his opinion of it. (qtd. in Mudrick, 1952:219)

According to Jung, the creativity of the artist appears in the literary ability to express his/her sentiments in a dramatic presentation, to personify their feelings in a living mood, rather stating them in a clear-cut and overt manner (1972: 176). Moreover, Booth's theory of the 'objectivity of fiction' substantiates the fact that the art of fiction "is essentially persuasive or rhetorical" in the sense that both the verbal style and narrative strategies are mediums reflecting the writer's point of view, although not in a manner that is manipulative (Booth, 1961:567).

\subsubsection{Austen's Intellectual Perspectives}

In Persuasion, Austen, on behalf of her heroine, Anne, reveals her sympathy with the navy as a source of national pride:

His genius and ardour had seemed to foresee and to command his prosperous path... He had distinguished himself, and early gained the other step in rank, and must now, by successive captures, have made a handsome fortune. She had only navy lists and newspapers for her authority, but she could not doubt his being rich; and, in favour of his constancy, she had no reason to believe him married. (Persuasion, 2007: 26)

Through the character of Captain Wentworth, the 'fine gentleman', and Admiral Croft, the 'man-ofwar'(Persuasion, 2007: 62), Austen reveals not only her political views about the officers of the Navy (i.e. their fortune, their ranks, their salaries) but also states that they hold charm and an attraction for young girls at home. That is, they are imbued with gallantry and bravery: "he had every thing to elevate him which general attention and deference, and especially the attention of all the young women, could do" (Persuasion, 2007: 63).

Even Sir Walter, who had previously disdained Captain Wentworth for his 'obscure birth', admires 'his superiority 
of appearance' that "he saw him repeatedly by daylight" and at last "prepares his pen, with a very good grace, for the insertion of the marriage in the volume of honour" (Persuasion, 2007: 216), i.e. Sir Walter is delighted at the end of the novel to add the name of Captain Wentworth to the book of Baronetage, which he regards as a gauge of nobility in the upper nineteenth-century society.

\subsubsection{Unjust Treatment of the Foible Characters in Contrast to the Central Ones}

Simpson criticises Austen for her inaccurate portrayal of her 'foible' characters, in the same way that she perfects her sensible protagonist; to him, she lacks "the eye of the skilful naturalist” (qtd. in O’Neill, 1970: 15). Austen creates one-dimensional characters, both to amuse and to create forward momentum in the plot. For example, in Persuasion, Austen limits the space occupied by Mr. Elliot in the life of Anne, on account of the fact that he is foolish and immature, while paying lavish attention to 'the prudent' Wentworth. Even Wentworth serves her central character: "Anne's being tempted, by some man of talents and independence, to enter a state for which she held her to be peculiarly fitted by her warm affections and domestic habits" (Persuasion, 2007: 25).

Furthermore, in the light of a psychological and biographical approach, it is important to shed light on the character of Jane Austen herself within the social network of relations, and among people of different manners. Her brother essentially describes her nature as conservative and ruminative:

Faultless herself, as nearly as human nature can be, she always sought, in the faults of others, something to excuse, to forgive or forget. Where extenuation was impossible, she had a sure refuge in silence. She never uttered either a hasty, a silly, or severe expression. In short, her temper was as polished as her wit ... She was tranquil without reserve or stiffness; and communicative without intrusion or self-sufficiency. (qtd. in O'Neill, 1970: 7).

This may explain why she wishes her protagonists to be sincere, refined and moral. Cecil terms this 'the moralrealistic view', in which she adopts a conviction that a man's duty in life is to be genteel and civilised, yet in an imperative way (qtd. in O'Neill, 1970: 33). Butler considers that Austen (like the great nineteenth-century novelists) manages to "change the reader's relationship to the consciousness of the central character" so that they become emotionally and intellectually engaged "rather than critically in the inward experience a novel has to offer" (Walder, 1896: 225). She relies on the reader sharing her beliefs and lessons through her major characters, such as the well-mannered Captain Fredrick Wentworth, the affectionate Marianne, and the prudent Elinor, etc.

Harding asserts, "the heroine is in some degree isolated from those around her by being more sensitive or of finer moral insights or sounder judgment" (Harding, 1940: 264). An example of this is Lady Middleton, in Sense and Sensibility, who acts as a 'well-bred wife' resigning herself to accompanying the Steeles who are malicious and importunate, and "gives her husband genteel reprimand on this subject five or six times every day" (1896: 66). Similarly, in Persuasion, Anne (who takes after Jane Austen to the greatest degree), enjoys the company of Mrs. Musgrove, yet she sees her as "not much educated, and not at all elegant" (2007: 35) and dislikes her close-minded elitism.

Marianne in Sense and Sensibility and Anne in Persuasion accord with Austen when it comes to their patterns of thinking: "Marianne, though always unwilling to join any of their parties, was persuaded by her mother, who could not bear to have her seclude herself from any chance of amusement, to go likewise" (Sense, 1896: 77). Similarly, "[Anne] had but two friends in the world to add to his list, Lady Russell and Mrs Smith" (Persuasion, 2007: 219).

In Sense and Sensibility "the heroines are still nearer perfection", Austen designates her heroine (like herself) as a typical representation of "sound judgment and good feeling"; however, "the social world may have material power over her, enough to make her unhappy" (Harding, 1940: 269). The heroine is inclined to be independent and self-reliant of those distasteful characters about her and therefore isolated. Marianne and Elinor, for instance, should be spending much of their time in the company of "malicious and importunate women", such as the Steele sisters, Mrs. Ferrars, and Fanny Dashwood (qtd. in O’Neill, 1970: 99). Elinor contrives to avoid them for their impertinence and sheer stupidity:

Elinor, with great civility, declined the proposal. Her sister was perhaps laid down upon the bed, or in her dressing gown, and therefore not able to come to them.

"Oh, if that's all," cried Miss Steele, "we can just as well go and see HER."

Elinor began to find this impertinence too much for her temper; but she was saved the trouble of checking it, by Lucy's sharp reprimand, which now, as on many occasions, though it did not give much sweetness to the manners of one sister, was of advantage in governing those of the other.(Sense, 1896:117)

Harding illustrates that "[Austen] is never a submissive alliance with the representatives of virtue and good feeling in her social world- there is only a selective alliance with certain aspects of their characters" (1972: 270).

\subsection{Why Does Austen Write}

This section explores Austen's concerns and the purposes behind her novels. On the one hand, it aims to tackle her critics (including Murdick) who regard her as writing for the sake of entertainment and delight, i.e. art for art's sake. Jane Austen is thought to write books for commercial profit, or special travel-book or booksellers. On the other hand, critics such as Williams regard her writing as social criticism, coated with irony and comedy. Harding and Jung, both well-known psychologists, provide not only an interpretation of Jane Austen's inner mind as 
that of a shrewd novelist, but also explore and scrutinise her art from a psychological perspective. Harding offers her readers a new meaning of her sensible characters, or those with foibles, and the social circumstances, while Jung judges the formation of the writer's psyche saying that "it is his art that explains the artist, not the insufficiencies and conflicts of his personal life; he establishes his own school of analytical psychology" (1972: 175).

\subsubsection{Art for Art's Sake}

Both readers and critics find Jane Austen's novels a source of delight, relief and entertainment. Austen is a skilled novelist at weaving diverse characters, ironical situations, comic scenes, social interaction and a joyful atmosphere. Macaulay comments that "We have no hesitation in placing Jane Austen, a woman of whom England is justly proud". Macaulay and Murdick liken her to William Shakespeare, in thatshe uses her art as a representation of the social world around her, with vivid descriptions and amusing relationships (qtd. in O'Neill, 1970: 6).

Moreover, Lewes is of the opinion that her works are 'art for art's sake'. Murdick agrees with Lewes that her art "is no more than interesting speculation". That is to say, Austen in Persuasion sends no message to her readers, as her main goal in writing it is "amusing and edifying her family". He adds that: "Persuasion is a partial failure as a work of art". As far as her bourgeois society is concerned, Persuasion is a novel of courtship and marriage. Schorer points out that it is a novel about marriage as 'a market place' and about the female as 'marketable'. Austen employs marriage and romantic subjects "as it performs to this day, the double function of entertainment through titillation and the conveying in palatable form a particular kind of philosophy of life" (qtd. in Walder, 1896: 208).

Schorer additionally observes that, Jane Austen discriminates between two orders of values: the moral and the material (Mudrick, 1952: 240). To exemplify this, Anne and Wentworth's engagement is regarded as emphasising Austen's viewpoint that these two bourgeois lovers recognise the role of a game that states that material conditions and moral conventions if amalgamated (not necessarily in an equal way) will lead to a comfortable life and a happy ending.

Furthermore, "her marriage to the handsome prince at the end is in the nature of a reward for being different from the rest and a consolation for the distresses entailed by being different" (Harding, 1940: 270). Jane Austen recapitulates her message in the last chapter: "Anne was tenderness itself, and she had the full worth of it in Captain Wentworth's affection" (Persuasion, 2007: 219). That is, Anne and Wentworth succeed in overcoming the conflict between two worlds of love and economics (i.e. internal and external pressure) and those of personal feelings and social facts.

Sense and Sensibility is seen by Lerner as 'after Emma, the undoubted masterpiece', contending that it is intended as comic relief. Austen has created a highly entertaining satirical novel. Her satire critiques the lavishness of social decorum, as well as the embarrassing situations of her snobbish caricatures. Yet Harding views satire as 'misleading', for "she has none of the underlying didactic intention ordinarily attributed to the satirist. Her mode is not missionary; it is the more desperate one of merely finding some mode of existence for her critical attitudes" (Harding, 1940: 271). Harding considers that the satirist should have a meaningful message behind his satire, not simply to entertain the associates of everyday life. From a psychological viewpoint, Harding observes that:

[Austen] had a deep need of their affection and a genuine respect for the ordered, decent civilisation that they upheld. And yet she was sensitive to their crudeness and complacencies and knew that her real existence depended on resisting many of the values they implied. The novels gave her a way out of this dilemma. This, rather than the ambition of entertaining a posterity of urbane gentlemen, was her motive force in writing. (Harding, 1940: 271)

For example, Mrs. Jennings and Mrs. Palmer are both rich subjects of satire in Sense and Sensibility.

Mrs. Jennings, Lady Middleton's mother, was a goodhumoured, merry, fat, elderly woman, who talked a great deal, seemed very happy, and rather vulgar. She was full of jokes and laughter, and before dinner was over had said many witty things on the subject of lovers and husbands; hoped they had not left their hearts behind them in Sussex, and pretended to see them blush whether they did or not. (Sense, 1896: 19)

Austen delineates Mrs. Palmer in the following terms: "It was impossible for any one to be more thoroughly goodnatured, or more determined to be happy than Mrs. Palmer" (Sense, 1896: 62). Although Mrs. Jennings and Mrs. Palmer are minor characters, they take control of their own happiness by satirising others or intervening in people's lives, unlike her Austen's heroines, Elinor and Marianne, who are both incapable of their own decisions and happiness. Readers view them as desirable characters due to their 'self-determination' and 'independence' (Anderson and Kidd). Richard Simpson sheds light upon the fact that Austen, in a satirical manner, "shows as admirable a discrimination in the characters of fools as of people of sense... a conversation full of wisdom and wit" (qtd. in O'Neill, 1970: 15).

However, despite a recognition of the serious dilemma posed by Austen "being intensely critical of people to whom she also has strong emotional attachments", Harding (along with other critics) disapproves of Austen's futile satire, since it invites the carefree enjoyment and mere entertainment of her all her readers (Harding, 1940: 272).

\subsubsection{Social Criticism}

Williams, in his article entitled 'The English Novel', states that "the paradox of Jane Austen is then the achievement of a unity of tone, of a settled and remarkably 
confident way of seeing and judging, in this chronicle of confusion and change" (Walder, 1896: 237). Williams further observes that, following the agricultural revolution, Austen observes a considerable improvement and expansion of the standard of living across the classes. Flattery, snobbery and moral pretension formulated the ruling standards within the English society at that time, but Austen draws the reader's attention to a new social experience: one that can be seen as a social and moral criticism. For example, in Persuasion she develops "an everyday uncompromising morality which is in effect separable from its social basis and which, in other hands, can be turned against it" (Walder, 1896: 238). She therefore moulds characters and actions with an aim of serving her reformative aim, i.e. amending the sickness of social behaviour in her society. In Sense and Sensibility, Austen undisguisedly criticises the extravagant parties of the upper class through Mrs. Jennings:

The dinner was a grand one, the servants were numerous, and every thing bespoke the Mistress's inclination for show, and the Master's ability to support it. In spite of the improvements and additions which they were making to the Norland estate, and in spite of its owner having once been within some thousand pounds of being obliged to sell out at a loss, nothing gave any symptom of that indigence which he had tried to infer from it;-- no poverty of any kind, except of conversation, appeared-- but there, the deficiency was considerable. (Sense, 1896: 125)

In this comic scene, Austen employs her satire to critique the lavishness of social decorum. The narrator employs humour to overtly criticise the financial exaggeration of the parties thrown by the upper class: "The comic part of her [Austen's] character illustrates admirably her capacity for keeping on good terms with people without too great treachery to herself" (Harding, 1940: 263). It is clear that Austen is highly aware of the 'crisis of the knowable community', which is a natural result of the growth of towns, cities and metropolis. Subsequently, the size of awareness, consciousness and realisation of the outside world is also deepened. As concluded by Williams, this is an awareness of the function of the objects and subjects, of observers, of what they desire and what needs to be known (qtd. in Walder, 1896: 235-6).

All the characters in Persuasion and Sense and Sensibility are fundamentally obsessed with being settled securely within the upper class and accompanying the aristocracy. Marriage and a profession are the main goals of the majority of her characters, in order to attain the superiority and the social standards of the upper class. For example, in Persuasion Lady Russell advises the youthful Anne to turn down Captain Wentworth's proposal, because "she had prejudices on the side of ancestry; she had a value for rank and consequence" (2007: 10). Yet when he returns as a wealthy naval officer, her viewpoint is completely altered. Austen writes in the final chapter: "Lady Russell, in spite of all her former transgressions, he could now value from his heart" (Persuasion, 2007: 219).
Austen argues her moral lessons and viewpoints through comparison and contrast. Harding adds that she provokes her readers to revolt against 'the moral horror of values', such as snobbery, social pretension, imprudence, to mention but a few. On the other hand, she also teaches her readers "the duty of the individual to immerse himself in the events about him and to accept his obligations to his acquaintances finely and squarely" (qtd. in O'Neill, 1970: 88-9). Responsibility is another lesson Austen intends her readers to learn. For example, Marianne in Sense and Sensibility suffers due to her imprudence and selfishness: "She was sensible and clever; but eager in everything: her sorrows, her joys, could have no moderation. She was generous, amiable, interesting: she was everything but prudent" (Sense, 1896: 4). Throughout the course of the novel, Marianne grows, both from the heartbreak of her experience with Willoughby, and from hearing that Edward, whom her sister loves, is engaged to Lucy Steele. Austen depicts her movingly in Chapter 37:

If you can think me capable of ever feeling--surely you may suppose that I have suffered NOW. The composure of mind with which I have brought myself at present to consider the matter, the consolation that I have been willing to admit, have been the effect of constant and painful exertion. (Sense, 1896: 138)

This moment of self-discovery and self-abasement represents Marianne's development from a reckless, selfish, indiscreet innocent into a prudent and self-controlled young woman, who is capable of managing her own sentiments and of supporting those around her. It is clear that a number of critics propound that Jane Austen conveys important moral messages through her novels Persuasion and Sense and Sensibility, and they are not designed merely for entertainment.

\subsubsection{To Survive}

Jane Austen's purpose for writing her novels has been a source of controversy among respected critics. Close examination of her psychological feelings, along with specific biographical notes, provides different interpretations from the point of view of Jung's theory of creativity. The core of his theory being that:

In the case of the work of art we have to deal with a product of complicated psychic activities - but a product that is apparently intentional and consciously shaped. In the case of the artist we must deal with the psychic apparatus itself. In the first instance, we must attempt the psychological analysis of a definitely circumscribed and concrete artistic achievement, while the second we must analyse the living and the creative human being as a unique personality. (Jung, 1930: 176)

To illustrate this, it is often considered that Anne's love affair in Persuasion is Jane Austen's own. In the light of the biographical approach, Anne's emotion "proves not merely the biographical fact that Jane Austen had loved, but the aesthetic fact that she was no longer afraid to say so" (Mudrick, 1952: 227). Additionally, the growth in Anne's 
mindset and personality resonates with Austen's own intellectual growth as a writer. None of Austen's previous heroines, by temperament or accident, equals Anne. At the same time, Austen writes Sense and Sensibility to consciously and manageably (if not fully) express her embedded condemnation of the ill-manners and sickness of the upper levels of her society. For example, Lucy Steele shows Colonel Brandon unusual respect and interest in an attempt to take advantage of his wealth and generosity:

As for Colonel Brandon, she was not only ready to worship him as a saint, but was moreover truly anxious that he should be treated as one in all worldly concerns; anxious that his tythes should be raised to the utmost; and secretly resolved to avail herself, at Delaford, as far as she possibly could, of his servants, his carriage, his cows, and his poultry. (Sense, 1896:154)

Austen here criticises Lucy's manipulative efforts, specifically also commenting on the hypocrisy and fake feelings of the upper class in general. Austen shows intelligence in that she avoids any conflicts or confrontation with "the social group having such ambivalence for her" (Harding, 1940: 270). She therefore employs her sweet-covered satire to send strong messages to her enemies and the people she detests.

Harding's theory of regulated hatred is worth noting as an aspect of Austen's novels. It is not one that signifies a degrading or underrating of her art, or scorning a remarkable novelist. Rather, Harding contends that "she succeeded admirably in expressing the gentler virtues of a civilised social order". He further asserts that "she was a delicate satirist, revealing with inimitable lightness of touch the comic foibles and amiable weaknesses of the people whom she lived among and liked" (Harding, 1940: 263).

Austen is described by Marilyn Butler in her article 'Jane Austen and the War of Ideas' as 'a Christian writer', due to the fact that she enhances "the score of good taste, and of practical utility, by her religion being not at all obtrusive". Jane Austen aims to detach herself from 'the ideological convulsions' spread in the nineteenth century, and for this reason, she was fully aware of handling her 'didactic content' (Walder, 1896: 224). Austen's brother described her as: "without the slightest affection she recoiled from everything gross. Neither nature, wit, nor humour, could make her amends for so very low a scale of morals" (qtd. in O'Neill, 1970: 8). She is characterised as being reserved and conservative, delicate and honest, religious and devout.

In his article 'Why Write?' Jean Paul Sartre (1949) discusses the 'regulating mission' of the writer, that he/she "neither foresees nor conjectures; he projects" (Sartre, 1949: 373). From this viewpoint, Austen reads her society, disdains its demerits and thus takes a decision of changing its incongruous aspects through her pen, and yet maintains an outstanding position in that same society. To survive as a novelist, and as a well-known member of the upper levels of her society, Austen as "a novelist, therefore, part of her aim was to find the means for unobtrusive spiritual survival, without open conflict with the friendly people around her whose standards in simpler things she could accept and whose affection she greatly needed" (Harding, 1940: 571). Moreover, Leo Bersani in 'A Future for Astyanax' (1976) accounts for releasing the imagination via language as a form of realism: a strategy to serve society by "containing and repressing its disorder with significantly structured stories about itself' (Walder, 1896: 245). Austen's Persuasion and Sense and Sensibility both partially form a spiritual and psychological outlet for Austen's hidden emotions and unrevealed thoughts.

The unique aspect of Austen's art is that she consciously uncovers the peculiarities of her society, and knows how best to 'represent' it. She favours making her readers laugh at the faults they tolerate in themselves and their friends. However, her intention is to exaggerate their faults in order to make fun of them, yet at the same time her satire could be viewed as "a mock assault and not genuinely disruptive ... Satire such as this is obviously a means of admonitions but of self-reservation" (Harding, 1940: 272). For example, many of her characters believe that hypocrisy is an unavoidable facet of human nature, and an essential component of polite society. In Sense and Sensibility, Fanny finds the cold and dull Lady Middleton to be "one of the most charming women in the world!" (1896: 123). The exclamation mark at the end suggests the insincerity, vanity and pretension involved in such false appraisal. Such an aesthetic gesture, single word, or even odd tone, is seen by Said as a break in the constraints of representation; realism must innovatively seek a new descriptive mode (Walder, 1896: 260).

Austen's narrative style renders her a modernist novelist. Austen develops 'a form of the signified', i.e. narrative structure itself, along with satirical speeches, ironic sentences and farcical conversations. Her narrative style is invented, but intentionally so, in order to be considered as 'art for art's sake', and for mere entertainment. As stated by Edward Said, she empties the sign, and degrades it in order to infinitely postpone its objective and to challenge, in a radical fashion, the age-old aesthetic of 'representation' (Walder, 1896: 261). To illustrate, Austen endeavours to highlight certain evils in her society and its social members, not through direct straightforward manner, but through an indirect and disguised manner.

\section{Conclusion}

The theory of regulated hatred is employed effectively in Jane Austen's novels Persuasion and Sense and Sensibility in order to revolutionise in a distinguished manner the ruling standards of her social groups and to furnish her society with polished and impeccable manners. This research has investigated and examined her narrative techniques, varying tones, art of representation, tyrannical style, intellectual perspectives, and unjust treatment of her characters, in the light of the psychological, biographical and New Historicist approach. Furthermore, Austen writes new kind of realism that she established both as a member 
of the upper levels of her society and as a novelist whose task is to improve its manners. Austen has been influenced by the philosophy of Descartes, Locke and Johnson, regarding literature as the barometer, inspiration and a guide of society, and that the narrative methods and procedures embody the circumstantial view of life.

Persuasion and Sense and Sensibility convey ethical, personal and emotional truths. In offering her readers two plots (right and wrong), two types of characters (prudent and imprudent), two orderly worlds (moral and material), Austen naturalises the didactic tradition. Intelligently, and with intent, she focuses on sensible, genteel and civilised characters, on the one hand, and satirises, disdains and dehumanises human foibles. Austen's goal behind modelling her characters is that her readers share both her beliefs and her lessons. Anne and Captain Wentworth, Marianne and Elinor are examples of well-mannered protagonists. Lucy Steele, Lady Middleton, Mrs. Palmer, Sir Walter and Mrs. Musgrove are representatives of hypocrisy, false appraisal, social pretensions, flattery and impertinence.

Austen's subtlety as a writer is such that the inattentive reader (as illustrated by Harding and Butler) may well remain unaware of this aspect of her work. It is the reader who bears the responsibility to choose the path he/she wishes to trace in the future. Austen's sense of responsibility to her audience goes beyond language, to discover non-verbal truths. Austen is an unconventional writer, focusing on the internal struggle with self-conscious efforts and realistic literary methods through which she establishes her moral enterprise of truth telling, and extends the limits of human sympathy.

The preoccupation of Jane Austen as a novelist is personal conduct. Her aim is to test the social norms and standards that govern human behaviour in a number of realistic situations. Austen is aware of the fact that, unlike the settled 'traditional' world, nineteenth-century society reveals an obsessive preoccupation with estates, incomes and social positions, which are seen as instigators of all relationships in society at that time, whether in relation to marriage, friendship or professional life, etc.

The methods and techniques witnessed in Austen's novels interlock with a new sense of awareness, with historical consciousness and social rapports. Her readers, she understands, are not passive, but active creators, and destroyers, of the values of both individuals and relationships. For this reason, she deliberately creates characters and actions with the intention of bringing about improvement. In this sense, Jane Austen relates to later writers, such as Coleridge, George Eliot and Matthew Arnold, in that she develops uncompromising everyday morality and social consciousness that is, in effect, separable from its social basis and economic growth. Morality is independent of class; ethics and morals are unchangeable through time.

The prominent theory, regulated hatred, is not only regarded as an aspect of Austen's art, but it is also a means of expression, a secured mask, and an aesthetic style with dual incentives: to change the mood and to ameliorate society, to laugh at the fools and to propel them into selfconsciousness.

New critical theories by critics such as D. W. Harding, C. J. Jung, Raymond Williams, Linda Hutcheon, and M. M. Bakhtin, provide a new significance and interpretation when applied to old or modern works of fiction, including for instance, William Shakespeare, Anton Chekov and George Orwell.

\section{References}

[1] Allen, George. Critics on Jane Austen. London: Unwin Ltd, 1970. Print.

[2] Anderson, Kathleen and Jordan Kith:"Mrs. Jennings and Mrs. Palmer: The Path to Female Self-determination in Austen's Sense and Sensibility". Jasna.org. 19 Jan. 2014. $<$ http://www.jasna.org/persuasions/printed/number30/anders on.pdf $>$. Web.

[3] Austen, Jane. Persuasion. England: An Electronic Classics Series Publication, 2007. Print.

[4] Austen, Jane. Sense and Sensibility. Manybooks.net.1896. $<\mathrm{http}: / /$ manybooks.net $>$. Print.

[5] Booth, Wayne C. "The Rhetoric of Fiction". 1961. 20 $0^{\text {th }}$ Century Literary Criticism. Ed. David Lodge. England: Longman, 1972. 565- 579. Print.

[6] Drake, Sylvia. "D. W. Harding and Austen's letters". LiveJournal.com. $16^{\text {th }}$ Mar. 2011. 2 Jan. 2014. $<$ http://misssylviadrake.livejournal.com/42528.html $>$. Web.

[7] Jung, Carl Gustav. "Psychology and Literature". 1930. 20 $0^{\text {th }}$ Century Literary Criticism. Ed. David Lodge. England: Longman, 1972. 565- 579. Print.

[8] Justice, George. "Fine Fresh Hatred". Athlone Press: Jasna.org, 1998.202014. $<$ http://www.jasna.org/bookrev/br162p20.html $>$. Web.

[9] Harding, D. W. "Regulated hatred: An Aspect of the Work of Jane Austen". Scrutiny, Vol. VIII, March 1940. 20 Century Literary Criticism. Ed. David Lodge. England: Longman, 1972. 565- 579. Print.

[10] Lascelles, Mary. Jane Austen and Her Art. London: Oxford, 1939. Print.

[11] Lester, D. James and Lester, D. James Jr. Writing Research Paper. $11^{\text {th }}$ ed. United States. Pearson education, inc. 2005. Print.

[12] Mckillop, Ian. "Obituary: Professor D. W. Harding”. The Independent. 3 May 1993. 2 Jan. 2014 $<$ http://www.independent.co.uk/news/people/obituaryprofessor-d-w-harding-2320717.html $>$. Web.

[13] Mudrick, Marvin. Jane Austen: Irony as Defense and Discovery. England: Princeton University Press, 1952. Print.

[14] Neill, S. Diana. A Short History of The English Novel. London: Jarrolds, 1951. Print. 
[15] O'Neill, Judith. Critics on Jane Austen. London: George Allen and Unwin Ltd, 1970. Print.

[16] Oxford Dictionary of English. $7^{\text {th }}$ ed. 2010. Print.

[17] Stevenson, Angus (Ed). Oxford Dictionary of English. England: Oxford, 2013. Print.

[18] $20^{\text {th }}$ Century Literary Criticism. Ed. David Lodge. England: Longman, 1972. 565- 579. Print.

[19] Peck, John and Coyle, Martin. Literary Terms and Criticism. England: Macmillian, 2002. Print.

[20] Pinion, F. B. A Jane Austen Companion: A Critical Survey and Reference Book. London: Macmillan, 1973. Print.
[21] Raith, John (Ed.). "History of Parliament Trust". British History Online, 1819. 14 Jan. 2014. <http://www.britishhistory.ac.uk/report.aspx?compid=47272>. Web.

[22] Sales, Roger. Jane Austen and representations of Regency England. London: Routledge, 1996. Print.

[23] Sartre, Jean-Paul. "Why Write?". 1949. 20 $0^{\text {th }}$ Century Literary Criticism. Ed. David Lodge. England: Longman, 1972. 565- 579. Print.

[24] Walder, Dennis. Approaching Literature: The Realist Novel. London: Routledge, 1896. Print. 